\title{
How does collegiality survive managerially led universities? Evidence from a European Survey
}

\author{
Giulio Marinia,b* and Emanuela Realeb
}

aCentre for Research on Higher Education Policies, Matosinhos, Portugal; bResearch Institute for Sustainable Economic Growth, National Research Council (IRCrES-CNR), Rome, Italy

\begin{abstract}
Today's universities are, accordingly to Clark's entrepreneurial model, sustained by managerialism, whereas collegialism may remain in contrast or work in a different way. More recent literature suggests the clash such as the potential for coexistence between managerialism and collegialism. The study analyses data from a survey of 26 universities in 8 European countries, focusing on middle managers (MMs). The results show that at the level of the individual institutions, there are notable positive correlations between the presence of collegial and of managerial cultures.

Multilevel regressions at institutional level are analysed, to 'predict' collegiality in light of the universities' managerial culture and other factors affecting organizational change: accountability; distribution of discretional power; funding; impact of quality assurance (QA) and evaluation. The results illustrate that in more managerial universities, collegial culture increases above all when MMs believe that distance-steering tools (QA and evaluation) have had positive impacts. We find that collegiality can indeed thrive, even when 'managerially led'.
\end{abstract}

Keywords: higher education; managerial culture; collegial culture; middle managers; entrepreneurial university

1. Managerialism and collegiality: trade-off or coexistence?

The seminal work by Burton Clark about the organizational change, namely towards entrepreneurial universities, is widely reckoned. In his words, the entrepreneurial university is pushed by managerialism (i.e. more line management), but even by 'collective entrepreneurial action' (Clark 1998, 4). Succinctly stated, 'collegiality is then put to work in a different way' (Clark 1998, 148). However, Clark himself was aware of the possible resistant and conservative role of collegialism, which would block the entrepreneurial university (Clark 1998, 131-132). Even the authority resembles this difference and clash. On the one hand, there is discipline-rooted authority: personal or collegial rule, guild and professional authority. On the other hand is enterprisebased authority: trusteeship and bureaucracy. These two sets of authority relate respectively to collegial and managerial cultures (Clark 1983, 107).

Managerialism is expected to assemble the traits of a complete organization, with positive outcomes in clarity of vision and strategy, rapidity of decision-making and efficiency through global management of resources. The collegial culture stresses different and seemingly opposing aspects: democracy among peers, the right of 
veto, dispersion of influence and authority and bottom-up influence in decisionmaking. But how does the managerialism impact the collegial model?

The first response to this question stressed the clash between the two cultures: the more a university is managerially led, the less it will be collegial, because the increasingly top-down structure of decision-making and the strengthening of accountability will detract from the individuality and the bottom-up voice of the peers. Accordingly to the literature (Shattock 2006; Ferlie, Musselin, and Andresani 2008), new public management (NPM) reforms will give impetus to managerialism and hinder collegiality, even though bypassing and evasive phenomena may arise as professionals try to defend themselves (Teelken 2012, 2015). Yet, too great emphasis on managerialism may bring about dangerous consequences, such as when it is presented in 'hard' version, impacting negatively the trust among scholars (Huisman and Currie 2004). In some case studies, managerialism indeed appears to be overpowering collegial bodies in determining the governance of universities (Carvalho and Santiago 2010). When managerialism involves the exercise of power by leaders and top-management figures, then a reduction in collegiality is observed to follow (de Boer, Goedegebuure, and Meek 2010). Other qualitative works suggest that academics still perceive themselves as the influential 'floor' of the system, exerting bottom-up pressure against the threat of top-down management and its corporate-inspired principles (Santiago and Carvalho 2012). The 'marketization' of higher education is seen as eroding collegiality in many continental European nations. Schimank (2005), for example, reported on managerialism as contributing to the demise of collegialism in German higher education. Leisyte (2014) detects scenarios of the changing role of scholars crisscrossing collective (more traditional and collegial) and individual (more managerial) features.

The traditional distribution of power in academic systems was termed 'collegial'; however the reality has been described as a sort of 'co-optation oligarchy' (Bensimon 1995; Hargreaves 1992). Scholars accepting this (essentially negative) view of collegiality have observed that, even though external pressures to some extent succeed imposing managerialism, the traditional assets of power within the oligarchies are simply reshuffled and reconstructed in order to minimize the changes. Collegialism, it is argued, has been developed as a sort of zero-sum game, where power is exercised by influential senior chairs and other dominant individuals in an oligarchy of guilds and fiefdoms (Trowler 2010). Carvalho and Santiago (2010) find that middle managers (MMs) tend to use their roles to permit the floor an opportunity of a hearing, and to appease the quests from that level.

Other authors argue a possible survival of collegialism in managerial universities. Deem (2008) and Macfarlane (2005) have shed light on the current roles of notscholars compared to those of 'rank and file' scholars in the rise of managerialism. Dill (2012) stresses that corporative approaches require more collective processes, especially in regard to issues of teaching and research. So, evidence and reflection have led to the conclusion that collegiality is a sort of 'evergreen' force that tends to fasten new managerial assets of whatever sort (Burnes, Wend, and Todnem By 2013). Under certain conditions, collegiality could actually be rejuvenated, rather than disappearing in a pitched battle against managerialism. However these in-depth case studies investigate only the UK or countries of similar tradition, while continental Europe remains even farther from full understanding. Even Meek et al. (2010) suggest the potential existence of various paths of co-development for the two cultures. The first would simply be a trade-off, where managerialism takes over 
at the expenses of collegiality. A second possibility is that only managerial rhetoric would diffuse, without true change in practice. A third, more probable option is the emergence of new hybrid models. Such hybridization may occur in the encounter of managerial requirements and traditional assets within governing bodies. Even when governing bodies are removed or deeply reformed under legislation, traditional norms and values may somehow continue to survive (Fulton 2003).

De Weert (2001) and Reed (2002) both conclude that managerialism and collegialism can coexist within a university. Tapper and Palfreyman $(2010,53)$ suggest that collegiality may find paths of enhancement in the new more managerialist environment. In countries where NPM does not have long-standing roots, the debate is open. Mignot-Gérard (2010) reports that managerialism is successfully enacted by the rectors or presidents who are able to give substance to the new culture. Boffo (2010) takes a position arguing more strongly for a thesis of balance between the two cultures. Analysing the French and Italian cases, he affirms that the introduction of managerial practices could find paths to permanence alongside the existing collegial traditions. Reale and Primeri (2014) instead focus on the persistence of the collegial aspect, despite legislative reforms and a willingness to overcome or reduce it.

In any case, the concepts of 'collegialism' and 'managerialism' have been enriched with new details over the years. Newton (2002) discussed 'new collegialism' as a potential positive response to demands for accountability. Harvey (1995) warned that accountability could bring about 'cloisterism', meaning a kind of negative collegiality, or 'new collegialism', which would be the positive response. 'Soft' managerialism - a managerialism leaving leeway of freedom to scholars - would be compatible with collegialism (Deem and Brehony 2005). Sahlin (2012) too suggests a decoupling of the two concepts. Hoecht (2006) has described how a high degree of managerialism could actually strengthen or generate collegialism among academics, stimulated by demands to report, to raise funds and accept some means of evaluation.

As a result, recent literature does not envisage a direct trade-off between managerial and collegial cultures as necessary. However the literature remains quite unclear on what influence the continued existence of collegial culture in a managerial context. Assuming that despite different paces in change and different path dependencies due to national differences, the quest for more managerialism in universities is nonetheless present and shared. But, under these circumstances, what is it that lets collegialism endure or even increase? Under what conditions can collegialism continue to serve the essential function of 'glue' within corporative universities?

The aim of the current study is to try to respond in an explorative way, to the mentioned questions by assuming the different degrees of managerialism at the institutional level as the basis of comparison among the universities. We start from the Clark's argument that a university, even an entrepreneurial one, is based on managerialism and, possibly, on collegialism. Despite the paces and paths are different, managerialism is a common phenomenon throughout Europe that recent reforms in higher education deeply pushed forward, generating organizational change within universities (Paradeise et al. 2009; Whitley 2010). Thus we want to shed light whether more managerial Universities are even those that are more collegial; if this is the case we can expect that: (i) the two culture basically coexist; (ii) collegiality is not hindered even in universities where managerialism largely affects the organizational change. 
The next section introduces the sources of analysis. Section 3 describes the presence of the two cultures at the institutional level in descriptive statistics, illustrating some features of the sample. Section 4 explains the factors of organizational change used as a set of predictors, of different modes of coexistence between managerialism and collegiality and then proceeds with the in-depth analysis and commentary. The conclusions highlight in what sense and under what circumstances the two cultures can live in symbiosis.

\section{Empirical basis, methodology}

The empirical focus of the study is on MMs (both deans and heads of departments), which today represent a key level in university organizational dynamics.

The study relies on a sample of 26 research universities 1 from eight European countries (France, Germany, Italy, Netherlands, Norway, Portugal, Switzerland and UK) collected within the EUROCORE-EUROHESC-TRUE project, which were selected in order to represent different types as to the age, the size, the orientation dividing between technical and generalistic universities. For each country, the sample include: (i) one generalistic and one technical university; (ii) one less prestigious university, with a low score on research intensity. As a proxy of research intensiveness, the Shanghai ranking index has been used where it seemed to work as an indicator. In the few cases where national universities were not registered by the index, research intensiveness has been identified in a way that makes sense nationally.

The data were collected in 2011, by means of questionnaires submitted to members of the governing bodies (Rector, Senate, Board, Central Administrator, MMs) of a total universe of 1420 people. From these, 697 valid responses were received (49\% rate). Within this, we consider the sub-universe of MMs, for which there are a total of 235 valid answers out of 491 total MMs (response rate of $47.9 \%$ ). The criteria for the sampling were to consider the widest possible range of different public universities, in term of size, age, discipline concentration and international standing. Cronbach's Alpha tests were run on single sets of Likert scales in order to measure reliability of the data collected. All the variables used satisfy the threshold of 0.6 or above that we assume in these variables high enough, considering the reduced number of items.

\section{Managerial and collegial cultures in the sample institutions}

To investigate the presence and relation of the two cultures in universities, two Likert scales are used. The respondents, regardless of the formal role they perform and the formal patters of the universities they were working in, had the opportunity to give an overall description of managerialism and collegialism (separately), assuming that they condensate the values, norms, beliefs and principles present in their universities. We assume in fact that scholars attribute about the same meaning to both 'managerial culture ' and 'collegial culture', throughout the countries and the universities. In more technical terms, considering the structure of the questionnaire, we consider those two Likert scale in face validity (one question goes straight to the subjective version of the concept) even though a description of a concept through more dimensions and indicators (construct validity) would be preferred under different circumstances (Gravetter and Forzano 2012, 71-106).

Interviewed declared the degree of managerialism and the degree of collegialism in their HEl.2 The academics perceive their universities as more collegial (mean 2.291) 
Table 1. General information and descriptive statistics of managerial and collegial culture per university, with Pearson's correlation.

Description of HEls

Managerial

Collegial

\begin{tabular}{|c|c|c|c|c|c|c|c|c|c|c|}
\hline HEls & Age & Size & Obs. & Mean & Std. dev. & Obs. & Mean & Std. dev. & $\mathrm{R}_{2}$ & $p$ \\
\hline NO1 & Old & Large & 19 & 3.211 & 0.7873 & 19 & 2.316 & 0.6710 & -0.1328 & \\
\hline $\mathrm{NO} 2$ & Old & Medium & 21 & 3.238 & 0.9437 & 21 & 2.381 & 0.7400 & 0.2216 & \\
\hline NO3 & Recent & Small & 10 & 2.700 & 1.0594 & 10 & 2.700 & 0.8233 & -0.4969 & \\
\hline $\mathrm{NO} 4$ & Old & Large & 22 & 2.409 & 0.7964 & 22 & 2.545 & 0.8004 & 0.0068 & \\
\hline IT1 & Recent & Medium & 43 & 2.488 & 0.7676 & 42 & 2.452 & 0.9423 & 0.1842 & \\
\hline IT2 & Old & Large & 46 & 2.696 & 0.9397 & 46 & 2.174 & 0.9263 & 0.5728 & $\star \star \star *$ \\
\hline IT3 & Old & Large & 30 & 2.400 & 1.0700 & 30 & 2.233 & 0.7739 & 0.0083 & \\
\hline PT1 & Recent & Small & 28 & 2.464 & 0.7445 & 28 & 2.714 & 1.2430 & 0.3888 & * \\
\hline PT2 & Old & Large & 34 & 2.559 & 1.0207 & 34 & 2.559 & 1.0785 & 0.1482 & \\
\hline PT3 & Recent & Medium & 19 & 2.789 & 0.8550 & 19 & 2.526 & 0.6967 & 0.1964 & \\
\hline NL1 & Recent & Medium & 14 & 2.500 & 0.7596 & 14 & 2.071 & 0.2673 & -0.1895 & \\
\hline NL2 & Old & Small & 20 & 2.900 & 0.7881 & 20 & 2.300 & 0.6569 & -0.0407 & \\
\hline NL3 & Old & Large & 19 & 2.263 & 0.7335 & 18 & 2.556 & 0.9835 & 0.0177 & \\
\hline DE1 & Old & Large & 13 & 2.000 & 0.9129 & 13 & 2.615 & 0.6504 & 0.0000 & \\
\hline DE2 & Old & Medium & 23 & 2.783 & 0.7952 & 22 & 2.500 & 0.8591 & 0.0390 & \\
\hline DE3 & Recent & Medium & 18 & 2.944 & 0.7254 & 20 & 2.400 & 0.6806 & 0.0455 & \\
\hline $\mathrm{CH} 1$ & Old & Small & 55 & 2.873 & 0.7948 & 55 & 2.491 & 0.8579 & -0.1239 & \\
\hline $\mathrm{CH} 2$ & Old & Medium & 33 & 2.515 & 0.8337 & 33 & 2.152 & 0.7124 & 0.0749 & \\
\hline $\mathrm{CH} 3$ & Old & Small & 15 & 1.667 & 0.8165 & 15 & 2.667 & 1.1127 & -0.0524 & \\
\hline $\mathrm{CH} 4$ & Recent & Small & 10 & 2.100 & 0.8756 & 9 & 2.000 & 0.8660 & 0.1555 & \\
\hline $\mathrm{CH} 5$ & Old & Small & 34 & 2.676 & 1.0363 & 34 & 2.118 & 0.6403 & 0.1504 & \\
\hline UK1 & Old & Medium & 37 & 2.297 & 1.0766 & 38 & 2.289 & 1.0374 & 0.5620 & $\star * * *$ \\
\hline UK2 & Recent & Large & 21 & 2.000 & 1.1832 & 21 & 2.619 & 0.8047 & 0.1575 & $\star \star * *$ \\
\hline UK3 & Old & Medium & 13 & 1.923 & 0.2774 & 13 & 2.231 & 0.8321 & -0.6389 & \\
\hline FR1 & Recent & Large & 45 & 3.067 & 1.1362 & 44 & 2.750 & 1.1437 & 0.4076 & ** \\
\hline FR2 & Recent & Medium & 25 & 3.360 & 0.9950 & 25 & 2.640 & 0.9074 & 0.2880 & $\star * *$ \\
\hline HEls & - & - & 26 & 2.567 & 0.5268 & 26 & 2.291 & 0.2725 & 0.0014 & \\
\hline MMs & - & - & 220 & 2.782 & 0.9640 & 219 & 2.475 & 0.9400 & 0.3242 & \\
\hline Total & - & - & 667 & 2.627 & 0.9695 & 665 & 2.424 & 0.8954 & 0.1760 & $* * *$ \\
\hline
\end{tabular}

Source: Own elaboration on TRUE data set.

Note: Old: established before 1968; recent: 1969 or after; size: small: up to 1000 enrolled students; medium: 1001-20,000; large: more than 20,001.

${ }_{* \star}<.05$.

*** $p<.001$. 
than managerial (mean 2.567), but for those identifying their organizational context as managerial, there is a slightly higher standard deviation $(0.5268$ and 0.2725 , respectively). In particular, the British, Dutch, Italian, Swiss and German universities are generally more managerial; French, Norwegian and Portuguese less so. Table 1 presents the details of the answers, by institution.

A further glance shows that among the whole sample, regardless of institutional affiliation, the two items of collegialism and managerialism have a positive and significant correlation of $0.176(\mathrm{p}<.000 ; \mathrm{N}=662)$. This slightly implies that the more the respondents believe their university is collegial, the more they believe it is also managerial. Restricting the sample to the MMs alone, the correlation is considerably higher $(0.324 ; p<.000 ; N=218)$. These characteristics all agree with the recent developments in the literature regarding the key role of MMs within universities (Meek et al. 2010). They are also fully consistent with a separate investigation based on this same sample of 26 European universities, which focused on the shift of universities towards 'complete organization' patterns (Seeber et al. 2014).

The evidence of Table 1 encourages us to inquire more deeply into how the individuals in academia, particularly MMs, come to recognize themselves as part of a managerial or collegial university, and whether this can be associated with other factors.

\section{Factors affecting organizational change in universities}

In today's universities, change (or any kind of reaction to changes in the external environment) is generally pushed by NPM and its modifications (Osborne 2006). External reforms can influence the extent to which a university is or becomes more managerial by using: accountability at the institutional level; new balances of discretional power; evaluation and quality assurance (QA) as distance-steering tools; new rationales for funding. The reforms and the contexts for their operation are national in level; however, it is clear that the concepts behind them are common across all the European countries, and can be analysed using common references (Paradeise et al. 2009). At the same time, it has been identified that the cultures existing at the university level can oppose reforms, where these are seen as promoting undesired change (Stensaker et al. 2012). We consider the importance of five factors in the coexistence of collegial and managerial cultures, which are often considered in the literature key items of organizational change (Brunsson and Sahlin-Andersson 2000; Sahlin 2012):

- Extent to which MMs have to be accountable to other governing bodies;

- Distribution of decision-making power at a certain level of the organization;

- Change of discretional power (increased or decreased) exercised by the different Governing bodies of the universities in both management and academic affairs (research and teaching);

- Degree of importance placed on performance in funding allocations;

- Impacts of 'steering at a distance' tools such as QA and evaluation.

\subsection{Accountability and decision-making power}

In recent years, universities have been more strictly obliged to provide reporting on what they do and how they work (McLendon, Hearn, and Deaton 2006), both 
internally and with external stakeholders. The obligations towards external stakeholders are in particular expected to boost managerial practices (Maassen 2000). Given this, institutional accountability should bring about more responsibility and virtuous behaviours, even though the actual outcomes may fail to establish such results (Capano 2010).

Despite the increasing role of external or upwards forms of accountability in academia (Stensaker and Harvey 2011, 245), in this study our variables refer to accountability at the internal level, in 'instrumental' mode. The study thus stresses the current governing power of MMs in relation to other personages, in order to understand to what extent the middle layers of the hierarchies must account to the superior levels. Such accountability is considered to be linked to the quest for managerial and tightcoupling assets (Ackroyd, Kirkpatrick, and Walker 2007). The path of MM accountability towards other actors is dependent on national context (de Boer, Enders, and Leisyte 2007); however, we assume that the accountability of MMs to other actors is in any case both relevant and comparable.

Decision-making power simply measures to what extent top management, MMs and shop floors have influence in several issues. The association of managerialism with the degree of power of the top management, for instance, is clear.

\begin{abstract}
4.2. Discretional power
Discretional power concerns the freedom of scholars to govern themselves. From the opposite perspective, the discretional power of governing bodies measures to what extent they can interfere with academics. In universities, discretional powers are not complete: scholars cannot achieve complete control over academic affairs but, at the same time, other bodies cannot completely control managerial affairs. Fluctuations in the mixtures of discretional powers influence the extent to which managerialism can be introduced in a particular university. For Olssen and Peters (2005), new forms of governmentality place greater emphasis on hierarchical powers, and can result in de-professionalization and mistrust (Harvey 1995), especially in situations when units such as departments are forced to cede their authority to the upper hierarchy (Taylor 2006). For this reason, it is relevant to understand to what extent MMs may have a voice in both the academic and managerial branches of university life in relation to managerialism and collegialism cultures.
\end{abstract}

\title{
4.3. Funding
}

Funding is a tangible lever for the accomplishment of change, especially given the current use of allocation mechanisms. One of the key aspects in the shift towards managerialism has been the introduction of criteria incorporating performance-based indicators in determining the allocation from government sources (Lepori et al. 2007). Funding has tended to shift from historically based criteria, with no change on the basis of performance, to formula allocations and negotiations based on performance indicators. In addition, the growing importance of project-based research funding in European countries is perceived as a push towards inter-university and inter-group competition. For project funding, the choice of the indicators used to measure the performance of a department or other middle levels (e.g. schools, faculties) can have a great effect on the development of competition. As a matter of fact, the influence of 
funding allocation criteria on collegiality in more managerially led universities is not yet fully explored or understood (Liefner 2003).

\section{4. $Q A$ and evaluation of research}

QA and the evaluation of research and teaching are commonly considered as distancesteering tools. They also have a crucial role in the determination of reputation and prestige (Whitley 2010). Within a given context, QA and evaluation can: (a) assist in legitimating assets already held; (b) influence how reputations are conveyed and the extent to which they count. The imposition of QA has been found that at times lead to rejection of the entire strategy; however, it can also induce positive reflection among academics on their ways of organizing themselves, offering room for increased effectiveness in universities with viable managerial cultures (Amaral 2014). According to Amaral (2014), issues of propriety and use and misuse in the implementation of QA also have intrinsic bonds with trust or mistrust in the given university.

Research evaluation systems are organized differently in the various countries; however, their presence does increment the necessity of coping with external pressures. Evaluation can also provide public and more transparent 'reputation' (Whitley 2007).

\footnotetext{
4.5. Variables in the data analysis

The data presented in Section 3 have shown that managerialism and collegialism increase and decrease in parallel with each other in a quite stable way. Given this, it would be interesting to understand which predictors might explain how, at the institutional level, the members of the governing bodies come to identify their universities as more collegial, given the degree of managerialism and other features. In Table 2, we thus develop the features above introduced. In the data analysis that follows, items of each feature represent single models for the explanation of collegialism at the institutional level, while also checking against the presence of managerialism.

Accountability is considered in terms of three variables, indicating the extent to which MMs must be accountable to: rectors (MM8_4); boards (MM8_3); senates (MM8_5) as they represent influent bodies and are present in all HEls under investigation.

Decision-making power is composed of three variables; under each variable, there is a total of 13 items dealing with key decisions on university government and management.3 For each item, all respondents are asked to indicate to what extent the power has been exerted by three levels: top level, middle and shop floor. Each score is on a scale of three points: high, some and low decision-making power. Thus the three variables (DMP_top; DMP_mm; DMP_sf) measure the actual decision-making power of the three levels, where each variable is the sum of the points for the 13 items. The data allow us to depict how the respondents perceive the distribution of decision-making power within the university.

Two questions are posed concerning discretional power. The first is: In recent years, how did the power of the following actors within your university change in relation to management affairs (leadership, budgets, accounting and administration)? (MM17 variables). The second was: In recent years, how did the power of the following actors within your university change in relation to academic affairs (teaching and research)? (POW variables). This distinction is interesting, since it separates discretional power at the
} 
Table 2. Variables used in the data analysis (all responses are given by MMs).

Variables

Feature

Content

Items

MM8_4

MM8_3

MM8_5

DMP_top

DMP $\mathrm{mm}$

DMP sf

MM1 $\overline{7} \_1-7$

\section{Accountability of MMs}

Decision-making power

Discretional power

In recent years, how each of the seven

actors has increased their discretiona

power, over
The extent to which MMs have to be accountable to other governing bodies

Actual decision-making power of the governing body over different types of strategic decisions

Leadership, budgets, accounting, administration
President/rector

Board

Senate

Top-management

MM

Shop-floor

Board

President/rector

Senate

Central administration

$\mathrm{MM}$

Individual academics

Board

President/rector

Senate

Central administration

MM

Chairs 
Table 2. Continued.

Variables

BUDGET_1-4 Funding

FRALLO_1-6

EVQA pos

EVQA neg
Feature

Content

Aims of the budgeting rules

Important factors in funding allocation

Evaluation and quality assessment (QA)

Source: Own elaboration.
Positive impacts of QA and evaluation

Negative impacts of QA and evaluation
Items

Increase the efficiency of university operations

Demonstrate to the Government that

the university is efficiently using

resources

Strengthen the power of the central administration

favour selected units

\# students enrolled in unit

\# graduates enrolled in unit

Level of external funds acquired by unit

Overall scientific reputation of the unit

Compliance with strategic university priorities

Relationship between the MMs and central management 
administrative and academic levels and fosters identification of the degree of influence exerted by seven actors, with each actor representing an item.

Two questions address funding allocation. One of these concerns the BUDGET 4 variable. This question collects perceptions about the reasons for introduction of budgeting rules. The concept is that funding allocation in the university is purposely unequal, and is administered according to rules that supposedly establish under which circumstances the different units can be funded, as indicated in the items. The question concerning the FRALLO variable takes a different perspective. It evidences the true factors that determine whether a unit is funded or not. In this second case, funding is assumed to be determined under rules that are already embedded in the university, meaning that the MMs would know what is influential and what is not. For this variable, the question is as follows: How important are each of the following factors in resource allocation to units? (1) Number of students enrolled in unit's curricula; (2) number of graduates enrolled in unit's curricula; (3) level of external funds acquired by the unit; (4) overall scientific reputation of the unit; (5) compliance with strategic university priorities.

Evaluation and QA are analysed through two variables assessing the actual impacts of these tools on the university, named EVQA_neg and EVQA_pos. The first variable is a sum of negative consequences, encompassing five items: (1) conflicts among academics; (2) conflicts between managers and academics; (3) academic activity subjected to more norms and rules; (4) opportunistic behaviours in teaching and research; (5) constraints on academic freedom. The second variable sums positive impacts, encompassing four items, describing the improvement of: (1) teaching quality; (2) research quality; (3) transparency; (4) strategic decision-making.

\section{Multilevel data analysis}

In this study, we assume that managerialism is an independent variable as MMs may see it as an external change. Collegialism on the other hand is seen as an opposing, dependent variable enacted by MMs or above characters, whose outcome can be positively or negatively associated with some factors, given the observed extent of managerialism.

We run the multilevel regressions to take into account the organizations as the main level that fits the research question (Snijders and Bosker 2012).

\subsection{Singles models}

Table 3 shows the full list of predictors as described in the previous section. Collegiality is the dependent variable and the predictors are managerialism and, separately, each of the variables considered. In all cases, managerialism is a positive and statistically significant predictor of collegiality, at least at 0.01 or below. The more the MMs must account to their rector (MM_8_4), the more the culture of the university is collegial, when the university is also more managerial (coeff. 0.1549). This indicates that bottom-up accountability triggers more collegial culture, but only if the one owed accountability is the rector. When managerialism is in place and accountability is owed to either the board (the most 'managerial' governing body) or the senate (the most 'collegial' body), collegial culture is not explained. 
Table 3. Predictors of degree of collegial culture, given managerialism (right column) and other features: multilevel regressions at the institutional level. Each row is a model.

\begin{tabular}{|c|c|c|c|c|c|c|c|c|}
\hline Obs. & & Coef. & Sig. & S.E. & & Coef. & Sig. & S.E. \\
\hline 171 & mm_8_3 & 0.0708 & & 0.0594 & uni_1 & 0.2032 & $\begin{array}{l}* * \\
* * *\end{array}$ & 0.0721 \\
\hline $\begin{array}{l}210 \\
173\end{array}$ & $\begin{array}{l}\mathrm{mm}=8-4-4- \\
\mathrm{mm} 85\end{array}$ & 0.1549 & & 0.0646 & & 0.3041 & $* * *$ & 0.0720 \\
\hline 187 & $\mathrm{dmp}$ top & 0.2663 & & 0.1545 & & 0.3269 & $* * *$ & 0.0662 \\
\hline 187 & dmp mid & 0.1297 & & 0.1614 & & 0.3311 & $* * *$ & 0.0675 \\
\hline 178 & dmp_sf & 0.2197 & & 0.1507 & & 0.3275 & *** & 0.0688 \\
\hline 146 & mm_17_1 & -0.0702 & & 0.0821 & & 0.2498 & $* * *$ & 0.0750 \\
\hline 195 & $\mathrm{~mm} 172$ & -0.0220 & & 0.0845 & & 0.3226 & $* * *$ & 0.0653 \\
\hline 150 & $\mathrm{~mm} 173$ & -0.1977 & & 0.0824 & & 0.3541 & *** & 0.0738 \\
\hline 190 & $\mathrm{~mm} 17 \_4$ & -0.0224 & 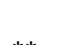 & 0.0811 & & 0.2975 & *** & 0.0671 \\
\hline 195 & $\mathrm{~mm} 175$ & 0.1410 & ** & 0.0662 & & 0.3188 & *** & 0.0643 \\
\hline 188 & $\mathrm{~mm} 176$ & 0.1375 & & 0.0800 & & 0.3054 & *** & 0.0652 \\
\hline 191 & $\mathrm{~mm} \_17 \_7$ & 0.0624 & * & 0.0817 & & 0.3212 & *** & 0.0652 \\
\hline 144 & pow_1 & -0.1740 & & 0.0884 & & 0.2130 & *** & 0.0689 \\
\hline 192 & pow_2 & -0.0972 & & 0.0864 & & 0.3061 & *** & 0.0614 \\
\hline 149 & pow 3 & -0.1261 & & 0.0835 & & 0.4023 & *** & 0.0700 \\
\hline 185 & pow 4 & -0.0675 & * & 0.0872 & & 0.2860 & $* * *$ & 0.0636 \\
\hline 192 & pow_5 & 0.1123 & & 0.0823 & & 0.3082 & *** & 0.0612 \\
\hline 207 & pow_6 6 & 0.2132 & & 0.0894 & & 0.2827 & *** & 0.0632 \\
\hline 191 & pow 7 & 0.1796 & & 0.0836 & & 0.3003 & *** & 0.0632 \\
\hline 178 & f_r_allo_1 & 0.0430 & & 0.0576 & & 0.1386 & ** & 0.0449 \\
\hline 181 & f_r_allo_2 & 0.1152 & & 0.0372 & & 0.1041 & * & 0.0449 \\
\hline 188 & frallo 3 & 0.0025 & * & 0.0553 & & 0.1598 & *** & 0.0458 \\
\hline 187 & $f r$ allo 4 & 0.1034 & * & 0.0382 & & 0.1378 & ** & 0.0449 \\
\hline 188 & f_r_allo_5 & 0.0567 & & 0.0616 & & 0.1489 & *** & 0.0461 \\
\hline 184 & frallo 6 & -0.0994 & *** & 0.0583 & & 0.1698 & *** & 0.0452 \\
\hline 185 & budget 1 & 0.1606 & & 0.0722 & & 0.2607 & *** & 0.0644 \\
\hline 181 & budget_2 & -0.0892 & & 0.0666 & & 0.3241 & *** & 0.0647 \\
\hline 181 & budget_3 & -0.1764 & ** & 0.0660 & & 0.3140 & $* * *$ & 0.0623 \\
\hline 177 & budget 4 & -0.0359 & & 0.0661 & & 0.2901 & $* * *$ & 0.0648 \\
\hline 197 & evqa neg & -0.1864 & & 0.0701 & & 0.3543 & $* * *$ & 0.0640 \\
\hline 200 & evqa pos & 0.3193 & & 0.0973 & & 0.2823 & *** & 0.0667 \\
\hline & & & ** & & & & & \\
\hline & & & *** & & & & & \\
\hline
\end{tabular}

Source: own elaboration on TRUE data set.

${ }^{*} p<.05$.

${ }_{* *}^{* *} p<.01$.

${ }^{* \star *} p<.001$.

Decision-making power, whether at the shop floor, middle or top-management levels, does not have any significant coefficients. These predictors were therefore not used in the model exposed in Table 4. This evidence is nonetheless coherent with Tapper and Palfreyman $(2010,160)$, who clearly state that collegiality is unaffected by any varying placement of decision-making power within the hierarchy.

Discretional power is shown to have a clearer role in defining and shaping the cultures. In fact, collegialism increases as MMs became more influential in issues concerning the administrative component of the university (MM_17_5; coeff. 0.1410). In contrast, the more the senate gains influence (MM_17_3; coeff. -0.1977$)$ and the 
Table 4. Single multilevel model to predict collegialism with effective features and managerialism $(\mathrm{N}=116)$.

$\begin{array}{lrlc} & \text { Coeff. } & \text { Sig } & \text { S.E. } \\ \text { uni_1 } & & & \\ \text { mm_8_4 } & 0.1858 & * & 0.0755 \\ \text { mm_17_5 } & 0.1783 & * & 0.0825 \\ \text { pow_1 } & 0.0491 & & 0.0896 \\ \text { pow_6 } & -0.0697 & & 0.1011 \\ \text { pow_7 } & 0.0396 & & 0.1457 \\ \text { f_r_allo_2 } & 0.0056 & & 0.1189 \\ \text { f_rallo_4 } & 0.0287 & & 0.0594 \\ \text { budget_3 } & -0.0383 & & 0.0619 \\ \text { evqa_neg } & -0.1122 & & 0.0752 \\ \text { evqa_pos } & -0.1591 & & 0.0956 \\ \text { cons. } & 0.3108 & & 0.1170 \\ & 0.1227 & & 0.5864\end{array}$

Source: Own elaboration on TRUE data set.

${ }^{*} \mathrm{p}<.05$.

${ }^{* *} p<.01$.

${ }^{* * *} p<.001$.

more the culture becomes less managerial, then the less the institution is collegial. Symmetrically, the more the Senate weakens in influence and the university is more managerial, the more the university gains collegiality. This evidence is interesting because it suggests that in highly managerial universities, the senate could actually result as a hindrance to the development of collegial culture. The influence of the senate (MM_17_3) was not included in the general model as it would have prevented the inclusion of several universities that have no senate at all (i.e. the Norwegian ones).

Still considering Discretional power, but now over academic issues (teaching and research), the data tell a story of mirror image effects. Now, when chairs and individuals are more influential, collegiality increases with more managerialism (Pow_6 and Pow_7; coeffs. 0.2132 and 0.1796 , respectively). On the contrary, more collegialism is associated with more managerialism when the boards have less power (Pow_1, coeff. $-0.1740)$. In all other cases, the coefficients are not statistically significant. This offers useful information about the capacity for academic issues to be 'ruled' both by a more widespread base of scholars, and by managerial bodies.

Regarding funding, when MMs perceive that new budgetary rules have been established with the purpose of strengthening the power of the central administration (BUDGET_3; coeff. -0.1764) and managerialism is higher, collegiality declines. This means that the shift of power over funding towards top management, in unison with a higher managerial culture, is associated with a loss of collegiality. Collegiality is instead explained with positive correlation when budgets are allocated according to the reputation of the units (FRALLO_2 coeff. 0.1034) and for number of graduates enrolled in the unit (FRALLO_4; coeff. 0.1152), where managerialism is also higher.

Regarding evaluation and QA, the aggregation of items clearly reveals that collegialism tends to decline where these tools are perceived as generators of conflicts and 
uncertainty, and where managerialism is higher. In contrast, collegial culture increases where the presence of evaluation and $Q A$ are perceived as having impacted positively (EVQA_pos; coeff. 0.3193, the highest among all regressions), managerialism also being higher. In coherence, negative effects of evaluation and QA let collegiality diminish, being managerialism equal (EVQA_net coeff. -0.1864).

\subsection{The overall model}

The general model provided in Table 4 attempts to determine which factors, among those that were significant in the previous discussion, are stronger. Managerial culture ('uni_1') is a positive predictor of collegiality (coeff. 0.1858 ), followed by only two other features that reach at least statistical significance: first is the perception of a positive impact from evaluation and QA (EVQA_pos; coeff. 0.3108); second is accountability of MMs towards the rector or president (MM_8_4, coeff. 0.1783). All in all, we can say that collegiality is higher in more managerial universities, provided especially that the rules of the game are seen as aimed at fair competition (EVQA_pos), and secondly when greater accountability is expected from MMs towards their rectors.

\section{Conclusions}

According to our exploration, collegiality is still present, and universities are still capable of self-regulating, despite the many deep changes that they have experience over recent years (Dill 2014). MMs are also still operating as a safety valve, or gateway, permitting any scholar to have a voice (Kekäle 2003). Indeed all forms of authority require some form of collegiality (Tapper and Palfreyman 2010, 168). Managerialism, in order to rule the university well, must also accommodate and guarantee room for some forms of collegialism, particularly to govern academic issues such as research and teaching. Collegialism is still a way getting things done within a given framework, and that framework can be more or less managerial. For MMs to carry out their key role, what appears to permit effectiveness is that they should have trust and confidence (Tierney 2008).

The aim of our study has been to determine if and how the co-presence of managerialism and collegialism can come about, and which factors permit the survival and improvement of collegialism in a managerially led context. The quantitative evidence appears consistent with our expectations: universities are peculiar organizations where the two cultures can coexist, without necessarily trading off one to the other. The clearest evidence is that collegialism, under conditions of higher managerialism and other factors held equal, is associated with distance-steering tools that have been enacted with positive impacts and with a stronger demanding role expressed by the leaders.

Given that managerialism is a rising trend throughout Europe, the next step would be to understand what permits mistrust to brew, or trust to blossom, at the basis of the academic sphere. Such information would be a further contribution towards more competitive and vital, in one word entrepreneurial, universities.

\section{Disclosure statement}

No potential conflict of interest was reported by the authors. 


\section{Funding}

This work was supported by Fundação para a Ciência e a Tecnologia [grant number PEst-OE/ CED/UI0757/2013 \& EXCL/IVC-PEC/0789/2012].

\section{Notes}

1. The universities and MMs retained anonymity.

2. The full statements are. My university has: (1) a strong managerial culture; (2) a strong collegial culture (1 is strongest; 5 lowest degree).

3. The items are: (1) selecting leadership; (2) selecting the heads of units; (3) Establishing the profile of a new position; (4) selecting a candidate for a new chair in a unit; (5) setting employment conditions for a new chair; (6) setting the rules and procedures for evaluations of units; (7) setting goals that units must achieve; (8) defining the budgets of units; (9) establishing new teaching programs; (10) setting the number of students for each curriculum; (11) evaluating academics' individual performance; (12) establishing research programs and research themes for research units; (13) defining policies for the management of academic staff.

4. Full wording is as follows: Budgeting rules have been introduced to: (1) Increase the efficiency of university operation; (2) demonstrate to the government that the university is efficiently using resources; (3) strengthen the power of the central administration; (4) favor selected units.

\section{Notes on contributors}

Giulio Marini is a post-doc researcher at CIPES, Portugal, since 2013. Since 2010 until 2013, he had worked in the field of Higher Education Studies at the Ceris-CNR (currently IRCRES), National Research Council, taking part in national and international projects. His previously held positions include Research Assistant, Modul Convenor and Assistant Lecturer at Sapienza University of Rome, where he completed the BA, MA (2002) and PhD (2009).

Emanuela Reale, Senior researcher at IRCRES CNR, is responsible for the Research Unit of Rome, being principal investigator in several international research projects on the transformation of higher education field, on the governance of public sector of research, and methods and instruments for research evaluation. She coordinates EC Projects on Indicators and Impact analysis of public research funding. She is a member of the Board of the European Network of Indicator Designers (ENID Association), a member of the Board of the Consortium of Higher Education Researchers (CHER), Vice President of the European Forum for Research and Policy Studies (Eu-SPRI). She published several works and serves as a reviewer in several journals on Higher Education and Research policy.

\section{References}

Ackroyd, S., I. Kirkpatrick, and R. Walker. 2007. "Public Management Reform and Its Consequences for Professional Organisation: A Comparative Analysis." Public Administration 85 (1): 9-26. doi:10.1111/j.1467-9299.2007.00631.x.

Amaral, A. 2014. "Where are Quality Frontiers Moving to?" In Quality Assurance in Higher Education. Contemporary Debates, edited by Maria João Rosa and Alberto Amaral, 13-31. Basingstoke: Palgrave.

Bensimon, E. 1995. "Total Quality Management in the Academy: A Rebellious Reading." Harvard Educational Review 65 (4): 593-612.

de Boer, H., J. Enders, and L. Leisyte. 2007. "Public Sector Reforms in Dutch Higher Education: The Organizational Transformation of the University." Public Administration 85 (1): 27-46. doi:10.1111/j.1467-9299.2007.00632.x.

de Boer, H., L. Goedegebuure, and V. L. Meek. 2010. "The Changing Nature of Academic Middle Management: A Framework for Analysis." In The Changing Dynamics of Higher Education Middle Management, edited by Vincent Lynn Meek, Leo Goedegebuure, Rui Santiago, and Teresa Carvalho, 229-241. Dordrecht: Springer. 
Boffo, S. 2010. "Middle-level University Managers in Italy: An Ambiguous Transition." In The Changing Dynamics of Higher Education Middle Management, edited by Vincent Lynn Meek, Leo Goedegebuure, Rui Santiago, and Teresa Carvalho, 103-117. Dordrecht: Springer.

Brunsson, N., and K. Sahlin-Andersson. 2000. "Constructing Organizations: The Example of Public Sector Reform." Organization Studies 21 (4): 721-746.

Burnes, B., P. Wend, and R. Todnem By. 2013. "The Changing Face of English Universities: Reinventing Collegiality for the Twenty-first Century." Studies in Higher Education 39 (6): 905-926. doi:10.1080/03075079.2012.754858.

Capano, G. 2010. "A Sisyphean Task: Evaluation and Institutional Accountability in Italian Higher Education." Higher Education Policy 23: 39-62. doi:10.1057/hep.2009.19.

Carvalho, T., R. Santiago. 2010. "New Public Management and 'Middle Management': How do Deans Influence Institutional Policies?" In The Changing Dynamics of Higher Education Middle Management, edited by Vincent Lynn Meek, Leo Goedegebuure, Rui Santiago, and Teresa Carvalho, 165-196. Dordrecht: Springer.

Clark, B. 1983. The Higher Education System: Academic Organization in Cross-national Perspective. Berkley: University of California Press.

Clark, B. 1998. Creating Entrepreneurial Universities: Organizational Pathways of Transformation. Oxford, MA: Pergamon Press.

Deem, R. 2008. "Unravelling the Fabric of Academe: The Managerialist University and its Implications for the Integrity of Academic Work." In Universities at Risk: How Politics, Special Interests and Corporatization Threaten Academic Integrity, edited by J. Turk, 256-281. Ottawa: James Lorimer.

Deem, R., and K. J. Brehony. 2005. "Management as Ideology: the Case of 'New Managerialism' in Higher Education." Oxford Review of Education 31 (2): 217-235. doi:10.1080/03054980500117827.

De Weert, E. 2001. "Pressures and Prospects Facing the Academic Profession in the Netherlands." Higher Education, 41 (1/2): 77-101.

Dill, D. 2012. "The Management of Academic Culture Revisited: Integrating Universities in an Entrepreneurial Age." In Managing Reform in Universities. The Dynamics of Culture, Identity and Organizational Change, edited by J. Välima, B. Stensaker, and C. Sarrico, 222-237. Basingstoke: Palgrave.

Dill, D. 2014. "Public Policy Design and University Reforms: Insights into Academic Change." In Reforming Higher Education. Public Policy Design and Implementation, edited by C. Musselin and P. Teixeira, 21-37. Dordrecht: Springer.

Ferlie, E., C. Musselin, and G. Andresani. 2008. "The Steering of Higher Education Systems: A Public Management Perspective." Higher Education 56 (3): 325-348. doi:10.1007/s10734008-9125-5.

Fulton, O. 2003. "Managerialism in UK Universities: Unstable Hybridity and the Complications of Implementation." In The Higher Education Managerial Revolution?, edited by A. Amaral, V. L. Meek, and I. M. Larsen, 155-178. Dordrecht: Kluwer Academic.

Gravetter, Frederick J., and Lori-Ann B. Forzano. 2012. Research Methods for the Behavioral Sciences. Belmont, CA: Wadsworth.

Hargreaves, A. 1992. "Contrived Collegiality: The Micropolitics of Teacher Collaboration." In Managing Change in Education: Individual and Organizational Perspectives, edited by Bennett M. Crawford and C. Riches, 80-94. London: Open University Press.

Harvey, L. 1995. "The New Collegialism. Improvement with Accountability." Tertiary Education and Management 1 (2): 153-160.

Hoecht, A. 2006. "Quality Assurance in UK Higher Education: Issues of Trust, Control, Professional Autonomy and Accountability." Higher Education 51 (4): 541-563. doi:10. 1007/s10734-004-2533-2.

Huisman, J., and J. Currie. 2004. "Accountability in Higher Education: Bridge over Troubled Water?" Higher Education 48 (4): 529-551. doi:10.1023/B:HIGH.0000046725.16936.4c.

Kekäle, J. 2003. "Academic Leaders as Thermostats." Tertiary Education and Management 9 (4): 281-298. doi:10.1023/A:1025822504242.

Leisyte, L. 2014. "Changing Academic Identities in the Context of a Managerial University Bridging the Duality Between Professions and Organizations Evidence from the U.S. and 
Europe." In The Relevance of Academic Work in Comparative Perspective, edited by W. K. Cummings and U. Teichler, 59-73. Dordrecht: Springer.

Lepori, B., M. Benninghoff, B. Jongbloed, C. Salerno, and S. Slipersaeter. 2007. "Changing Models and Patterns of Higher Education Funding: some Empirical Evidence." In Universities and Strategic Knowledge Creation: Specialization and Performance in Europe, edited by A. Bonaccorsi and C. Daraio, 85-111. Cheltenham: Edward Elgar.

Liefner, I. 2003. "Funding, Resource Allocation, and Performance in Higher Education Systems." Higher Education 46 (4): 469-489. doi:10.1023/A:1027381906977.

Maassen, P. 2000. "The Changing Role of Stakeholders in Dutch University Governance." European Journal of Education 35 (4): 449-464. doi:10.1111/1467-3435.00039.

Macfarlane, C. 2005. "The Disengaged Academic: The Retreat from Citizenship." Higher Education Quarterly 59 (4): 296-312. doi:10.1111/j.1468-2273.2005.00299.x.

McLendon, M., J. Hearn, and R. Deaton. 2006. "Called to Account: Analyzing the Origins and Spread of State Performance-Accountability Policies for Higher Education." Educational Evaluation and Policy Analysis 28 (1): 1-24. doi:10.3102/01623737028001001.

Meek, V. L., L. Goedegebuure, R. Santiago, and T. Carvalho, eds. 2010. The Changing Dynamics of Higher Education Middle Management. Dordrecht: Springer.

Mignot-Gérard, S. 2010. "Presidents and Deans in French Universities: A Collective Approach to Academic Leadership." In The Changing Dynamics of Higher Education Middle Management, edited by Vincent Lynn Meek, Leo Goedegebuure, Rui Santiago, and Teresa Carvalho 119-143. Dordrecht: Springer.

Newton, J. 2002. "Barriers to Effective Quality Management and Leadership: Case Study of Two Academic Departments." Higher Education 44 (2): 185-212. doi:10.1023/A:1016385207071.

Olssen, M., and M. A. Peters. 2005. "Neoliberalism, Higher Education and the Knowledge Economy: From the Free Market to Knowledge Capitalism." Journal of Education Policy 20 (3): 313-345. doi:10.1080/02680930500108718.

Osborne, S. 2006. “The New Public Governance?" Public Management Review 8 (3): 377-387. doi:10.1080/14719030600853022.

Paradeise, C., E. Reale, I. Bleiklie, and E. Ferlie, eds. 2009. University Governance. Western European Comparative Perspective. Dordrecht: Springer.

Reale, E., and E. Primeri. 2014. "Reforming Universities in Italy: Toward a New Paradigm?" In Reforming Higher Education. Public Policy Design and Implementation, edited by C. Musselin and P. Teixeira, 39-63. Dordrecht: Springer.

Reed, M. 2002. "New Managerialism, Professional Power and Organizational Governance in UK Universities: A Review and Assessment." In Governing Higher Education: National Perspectives on Institutional Governance, edited by A. Amaral, G. A. Jones, and B. Karseth, 163-186. Dordrecht: Kluwer Academic.

Sahlin, K. 2012. "The Interplay of Organizing Models in Higher Education: What Room is there for Collegiality in Universities Characterized by Bounded Autonomy?" In Managing Reform in Universities. The Dynamics of Culture, Identity and Organizational Change, edited by J. Välima, B. Stensaker, and C. Sarrico, 198-221. Basingstoke: Palgrave.

Santiago, R., and T. Carvalho. 2012. "Managerialism Rhetorics in Portuguese Higher Education." Minerva 50 (4): 511-532. doi:10.1007/s11024-012-9211-9.

Schimank, U. 2005. "New Public Management and the Academic Profession: Reflections on the German Situation." Minerva 43 (4): 361-376. doi:10.1007/s11024-005-2472-9.

Seeber, M., B. Lepori, M. Montauti, J. Enders, H. de Boer, E. Weyer, I. Bleiklie, et al. 2014. "European Universities as Complete Organizations? Understanding Identity, Hierarchy and Rationality in Public Organizations." Public Management Review. doi:10.1080/ 14719037.2014.943268.

Shattock, M. 2006. Good Governance in Higher Education. London: Open University Press.

Snijders, T., and R. Bosker. 2012. Multilevel Analysis. An Introduction to Basic and Advanced Multilevel Modeling. London: Sage.

Stensaker, B., and L. Harvey. 2011. Accountability in Higher Education. Global Perspectives on Trust and Power. New York: Routledge.

Stensaker, B., M. Henkel, J. Välima, and C. Sarrico. 2012. "Introduction: How is Change in Higher Education Managed?" In Managing Reform in Universities. The Dynamics 
of Culture, Identity and Organizational Change, edited by J. Välima, B. Stensaker, and C. Sarrico, 1-16. Basingstoke: Palgrave.

Tapper, T., and D. Palfreyman. 2010. The Collegial Tradition in the Age of Mass Higher Education. Dordrecht: Springer.

Taylor, J. 2006. "Big is Beautiful. Organisational Change in Universities in the United Kingdom: New Models of Institutional Management and the Changing Role of Academic Staff." Higher Education in Europe 31 (3): 251-273. doi:10.1080/03797720601058724.

Teelken, C. 2012. "Compliance or Pragmatism: How do Academics Deal with Managerialism in Higher Education? A Comparative Study in Three Countries." Studies in Higher Education 37 (3): 271-290. doi:10.1080/03075079.2010.511171.

Teelken, C. 2015. "Hybridity, Coping Mechanisms, and Academic Performance Management: Comparing Three Countries." Public Administration 93 (2), 307-323. doi:10.1111/padm. 12138.

Tierney, W. G. 2008. "Trust and Organizational Culture in Higher Education Education." In Cultural Perspectives on Higher Education, edited by J. Välimaa and O. Ylijoki, 27-41. Dordrecht: Springer.

Trowler, P. R. 2010. "UK Higher Education: Captured by New Managerialist Ideology?." In The Changing Dynamics of Higher Education Middle Management, edited by Vincent Lynn Meek, Leo Goedegebuure, Rui Santiago, and Teresa Carvalho, 197-211. Dordrecht: Springer.

Whitley, R. 2007. "Changing Governance of the Public Sciences. The Consequences of Establishing Research Evaluation System for Knowledge Production in Different Countries and Scientific Fields." In The Changing Governance of the Sciences. The Advent of Research Evaluation Systems, edited by R. Whitley and J. Gläser, 3-26. Dordrecht: Springer.

Whitley, R. 2010. "Reconfiguring the Public Sciences: The Impact of Governance Changes on Authority and Innovation in Public Science Systems." In Reconfiguring Knowledge Production. Changing Authority Relationships in the Sciences and their Consequences for Intellectual Innovation, edited by R. Whitley, J. Gläser, and L. Engwall, 3-47. Oxford: Oxford University Press. 